\title{
A revision of the Mediterranean Raphitomidae (Gastropoda, Conoidea), 7: on the sibling species Raphitoma densa (Mon- terosato, (884) and R. griseomaculata n. sp.
}

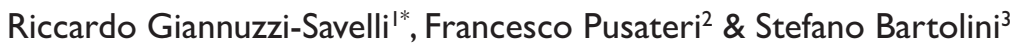 \\ ${ }^{1}$ Via Mater Dolorosa 54, 90146 Palermo, Italy; e-mail: malakos@tin.it \\ ${ }^{2}$ Via Castellana 64, 90135 Palermo, Italy; e-mail: francesco@pusateri.it \\ ${ }^{3}$ Via E. Zacconi 16, 50137 Firenze, Italy; e-mail stefmaria.bartolini@libero.it \\ ${ }^{*}$ Corresponding author
}

\begin{abstract}
A new raphitomid toxoglossa, Raphitoma griseomaculata n. sp. (Gastropoda Conoidea), is described from the Ionian Sea. It is the sister species to $R$. densa (Monterosato, 1884) from which it differs in the different protoconch (paucispiral vs. multispiral), adding to a long list of pairs of the cenogastropod species that differ in their larval development.
\end{abstract}

KEY WORDS

Raphitoma; sister cryptic species; new species.

Received 16.11.2018; accepted 07.12.2018; printed 30.12.2018; published online 07.01.2019

\section{INTRODUCTION}

The Raphitomidae Bellardi, 1875 are currently considered as a well supported clade of the Conoidea (Bouchet et al., 2011), worthy of family ranking. It is probably the most diverse family of Conoidea, in terms of species richness, ecological range and anatomical disparity (Kantor \& Taylor, 2002), and are therefore considered as potentially ideal candidates for toxin discovery (Puillandre et al., 2014).

We are currently revising the Raphitomidae of the Mediterranean Sea and the adjacent Atlantic coasts, of which we provisionally estimated ca. 47 Mediterranean extant species, some of which still undescribed. The taxon Raphitomidae Bellardi, 1875 is based on the genus Raphitoma Bellardi, 1847 which was introduced as comprising 34 fossil and Recent species (Bellardi, 1847: 85), previously classified in various genera (such as Pleurotoma
Lamarck, 1799 and Clathurella Carpenter, 1857). During this revision, we have found several pairs of species in the genus Raphitoma, differing only or mostly in the size and shape of the protoconch, with one member bearing a multispiral protoconch and the other member with a paucispiral protoconch. The specific distinction is based on the assumption that the dichotomy multispiral protoconch/planktotrophic development vs. paucispiral protoconch/lecithotrophic development (Jablonski \& Lutz, 1980) can be used in caenogastropods to recognise distinct sister species (Bouchet, 1989; Oliverio, 1996a, 1996b, 1997). However, it should not be abused to create polyphyletic genera by artificially separating closely related species among different genera only based on their larval development (Bouchet, 1990). In raphitomids, the separation of Raphitoma (multispiral protoconch) and Raphitoma a (paucispiral protoconch) is thus inconsistent and must be rejected. 
In a recent paper (Manousis et al., 2018), it is suggested an intriguing hypothesis about a possible poecilogony in Raphitomidae, but unfortunately no evidences are showed.

In the genus Raphitoma Bellardi, 1847, we have scored a dozen of such pairs of species with different protoconchs (multispiral vs. paucispiral) (Giannuzzi-Savelli et al., 2018).

In the present work, we present the case of Raphitoma densa (Monterosato, 1884) of which we have examined the type material and selected a lectotype with multispiral protoconch and its unnamed sister species with paucispiral protoconch.

\section{MATERIAL AND METHODS}

Our approach was exclusively based on shell morphology due to the almost total lack of anatomical data.

Specimens were studied from materials housed at several European museums and from private collections (see abbreviations). Unless otherwise stated, the shells originated after sorting bioclastic sand samples collected between 0-80 m depth.

SEM images were taken by Andrea Di Giulio at the "LIME" (Interdepartmental Laboratory of Electron Microscopy - Roma Tre University). Light photographs were taken (if not otherwise stated) by Stefano Bartolini using a Canon EOS 400D digital photocamera, with standard objective $50 \mathrm{~mm}+$ adapted objectives (25 and $12.5 \mathrm{~mm}$ ) for 16 and 8 $\mathrm{mm}$ vintage cine camera and by Riccardo Giannuzzi Savelli using a Canon EOS 45D mounted on a Kyowa binocular microscope, assembled with Helicon Focus 6 software and background removed with Clipping Magic.

ABBREVIATIONS AND ACRONYMS. Institutions. HUJ: Hebrew University of Jerusalem (Israel); MCZR: Museo Civico di Zoologia, Roma (Italy); MNHN: Musée Nationale Histoire Naturelle, Paris (France); MRSNT: Museo Regionale Storia Naturale, Terrasini (Italy); SMF: Senckenberg Museum, Frankfurt/M (Germany); SMNH: Swedish Museum of Natural History, Stockholm (Sweden). Collections. AHU: José Ahuir (Spain), BAR: Stefano Bartolini (Firenze, Italy); CAR: Alberto Caruso (Sapri, Italy); COL: Giuseppe Colamonaco†; CRO: Paolo Crovato (Napoli, Italy); DES: Flavio De Santis (Roma, Italy); DON:
Mauro Doneddu (Tempio Pausania, Italy); DUR: Sergio Duraccio (Napoli, Italy); FIO: Angelo Fiorita (Lecce, Italy); GER: Alfio Germanà (Trecastagni, Italy); GIR: Antonio Girgenti (Palermo, Italy); MAC: Gabriele Macrì (Lecce, Italy); MAR: Alessandro Margelli (Santa Maria al Monte, Italy); MEL: Nicola Melone (Bari, Italy); NOF: Italo Nofroni (Roma, Italy); OLI: Marco Oliverio (Roma, Italy); PAG: Attilio Pagli (Lari, Italy); PAL: Alberto Palmeri (Palermo, Italy); PAO: Paolo Paolini (Livorno); PIS: Michele Pisanu (Quartu S. Elena, Italy); PUS: Francesco Pusateri (Palermo, Italy); RAV: Alessandro Raveggi (Firenze, Italy); RUF: Stefano Rufini (Anguillara Sabazia, Italy); SER: Gabriele Sercia (Palermo, Italy); SMR: Carlo Smriglio (Roma, Italy); SOS: Maurizio Sosso (Genova, Italy); TRI: Lionello Tringali (Roma, Italy); VAZ: Angelo Vazzana (Reggio Calabria, Italy); VIL: Alberto Villari (Messina, Italy). sh: empty shells; WI: wrong identification; H: height; W: width; DS: standard deviation.

\section{RESULTS}

\section{Systematics}

(Citation of unpublished names is not intended for taxonomic purposes)

Classis GASTROPODA Cuvier, 1795

Subclassis CAENOGASTROPODA Cox, 1960

Ordo NEOGASTROPODA Wenz, 1938

Superfamilia CONOIDEA J. Fleming, 1822

Familia RAPHITOMIDAE Bellardi, 1875

Genus Raphitoma Bellardi, 1847. Type species: Pleurotoma hystrix Cristofori and Jan, 1832 (nomen nudum, validated by Bellardi (1847) as "Pleurotoma histrix Jan.") by subsequent designation (Monterosato, 1872: 54).

Cordieria Monterosato, 1884 non Roualt, 1848. Type species: Murex reticulatus Brocchi, 1814, by subsequent designation (Crosse, 1885).

Philbertia Monterosato, 1884.Type species: Pleurotoma philberti Michaud, 1829 by subsequent designation (Crosse, 1885).

Cyrtoides F. Nordsieck, 1968. Type species: Pleurotoma rudis Scacchi, 1836, by original designation. 
Raphitoma densa (Monterosato, 1884) [Philbertia] Nomenclatura generica e specifica: 133 - Figs. $1-19,23-24,31$

Pleurotoma versicolor var. cinereomaculata Scacchi, 1836: 13 (nomen nudum)

Philbertia densa Monterosato, 1884: 133

Clathurella decorata pars Locard, 1891: 67 (lectotype selected herein)

Clathurella bucquoyi pars Locard, 1891 not Locard, 1886

Philbertia densa Carus, 1893: 425

Philbertia densa Pallary, 1900: 256

Philbertia purpurea var. densa Pallary, 1912: 83

Clathurella densa Hidalgo, 1917: 247

Philbertia densa Monterosato, 1917: 25

Raphitoma philberti densa Nordsieck, 1968: 177

Raphitoma philberti var. densa Parenzan, 1970: 212

Raphitoma (Ph.) flavida Nordsieck, 1977: 54, pl. 17 n. 132 (lectotype selected herein)

Raphitoma (Philbertia) bourguignati tarentina Nordsieck, 1977: 55 pl. 17 n. 136

Raphitoma (Philbertia) densa Piani, 1980: 157

Philbertia densa Sabelli et al., 1990: 45, 217

Raphitoma bicolor sensu Poppe \& Goto, 1991 non Risso, 1826: pl. 35 n. 20

Raphitoma densa Cachia et al., 1993: 34

Raphitoma (Philbertia) densa Delamotte \& Vardala-Theodoru, 1994: 287

Philbertia densa Arduino et al., 1995: 95 (figured)

Raphitoma densa Cachia et al., 2001: 65 pl. 10 fig. $1(\mathrm{WI}=R$. lineolata $)$

Raphitoma densa Cretella et. al., 2005: 121

Raphitoma densa Repetto et al., 2005: 217 n. 893 (figured)

Raphitoma densa Trono, 2006: 68

Raphitoma contigua Monterosato, sensu Cossignani \& Ardovini, 2011: 325

Raphitoma densa Cossignani \& Ardovini, 2011: 325 (only fig. a)

Raphitoma densa Repetto et al., 2011: 41,135

Raphitoma densa Manousis, 2012: 178 (figured)

Raphitoma densa Trono \& Macrì, 2013: 35

Raphitoma densa Scaperrotta et al., 2018: 21, 78 (figured) Raphitoma densa Manousis et al., 2018: 10, figs. $7 \mathrm{~b}-\mathrm{h}$

ORIGINAL DIAGNOSIS (Monterosato, 1884). "P. densa, Monts. $($ nov. Forma) $=$ Pl. versicolor, var. cinereo maculata, Sc. ex typo (Nap.). Reticolazione fitta, colorito fosco a macchie dense cineree o cerulee. Cette (Maltzan f. Verkruzen); Corsica (Nevill); Livorno (Caifassi); Civitavecchia (Del Prete); Malta (Medlycott); Alessandria (Gaudion); Falera (Morlet); Palermo e Trapani (Monts.)".

\section{TyPe LOCALITY. Palermo}

EXAMINED MATERIAL. The type material and:

Atlantic. Portugal - Algarve, $1 \mathrm{sh}(\mathrm{MNHN}), 2 \mathrm{sh}$ (SMNH lot 73393c); Ponta da Baleeira, Sagres, Algarve, 2 sh (SMNH lot 73393c).

Mediterranean. unprecised locality, 2 sh (SMNH lot 73180). Alboran Sea, 3 sh (OLI).

Spain - Algeciras, 1 sh (CRO); Fuengirola, 1 sh (SMNH lot 73169); Malaga, 1 sh (RUF), 1 sh (AHU); Punta de la Mona, 2 sh (BAR); Cabo de Gata Los Escullios, 1 sh (CRO); Getares, 1 sh (PAG); Baleares Isl., 1 sh (MNHN Paris, ex coll. de Brieux); Barcelona, - 40 m, 1 sh (PAO).

France. Provence, 2 sh (MCZR-M-16807); Roussillon, 2 sh (MCZR-M-16807); Bandol, Var, 1 sh (MCZR-M-16807); S. Raphael, 2 sh (MNHN coll. Locard), 2 sh (MNHN coll. Couturier sub nomine $C l$. corbiformis), 11 sh (MCZR-M-16807), 2 sh (MCZR-M-16794), 1 sh (HUJ coll. Coen lot 1914A sub nomine Philbertia purpurea bicolor, with Coen label), 1 sh (MCZR-M-16785) sub nomine ms. acutalis; Embiez Isl., Provence, 10 sh (MNHN); Provence, legit Claudio Ebreo 1 sh (PUS). Corse. Baie de Calvi, 2 sh (SMNH lot 73171F), 1 sh (SMNH lot 73172A), 1 sh (PUS); Ile Rousse, $>10$ sh (BAR); Ajaccio, 1 sh (CRO).

Italy. Capo Noli, Savona, 1 sh (RUF); Laconella, Elba Isl., -6 m, 2 sh (CRO); Capraia Isl., 1 sh (BAR); Giannutri Isl., 3 sh (SMR), 1 sh (BAR); Punta Ala, Grosseto, 10 sh (BAR); Antignano, -8 m, 1 sh (PAO); Golfo di Baratti, -10 m, 3 sh (PAO); Baratti, Livorno, 1 sh (PAG); 1 sh. (PAG); Castiglioncello, Livorno, 4 sh (MAR), 2 sh (PAO), 3 sh (PAG), 1 sh (MCZR-M16807); Punta Ala (Grosseto), 2 sh (GER), 2 sh (PAG); Talamone (Grosseto), 6 sh (RUF); Secca delle Vedove, Livorno, 3 sh, -100/130 (PAO); Latium, 1 sh (GIR); Ladispoli, Latina, 1 sh (DES); S. Agostino, Gaeta, Latina, 1 sh (CRO); Capri Isl., 2 sh (HUJ, coll. Coen lot 9473B, sub nomine "Philbertia purpurea prolixa ms", ex coll. Bellini), 1 sh (MCZR-M-16807), 1 sh (CRO); Procida Isl., 1 sh (MAR), 3 sh (CRO); Napoli, 2 sh (HUJ coll. Coen, lotto 9473. A sub nomine Philbertia purpurea prolixa ms), 1 sh (MCZR-M-16788), 1 sh (SMNH lot 
70492A), 4 sh, (MCZR-M-16807; Bacoli Punta Pennata, 1 sh (CRO); Marina di Puolo, Napoli, 1 sh (DUR); Punta Pioppeto (Ischia Isl.), 1 sh (PUS), 1 sh. (PAG), 4 sh (CRO); Sapri, Salerno, 1 sh (CAR); Secca di Pellaro, Reggio Calabria, 1 sh (PAO); Scilla, Reggio Calabria, 15 sh (VAZ); Taranto, 2 sh (MCZRM-16813 sub nomine ms. "specialis"), 2 sh (MCZRM-16807); Otranto, Lecce, 1 sh (MAC); Torre Serpe, Otranto, Lecce, 2 sh (MAC); Novaglie, Lecce, 1 sh (MAC); San Cataldo, Lecce, -6 m, 2 sh (CRO); Marina di Ugento, Lecce, 2 sh (MAC); Nardò, Lecce, 1 sh (COL); Porto Cesareo, Lecce, 2 sh (CRO), 6 sh (FIO); Cala Rena, Giovinazzo, Bari, 1 sh (MEL); Giovinazzo, Bari, 12 sh (MEL).

Sardinia. Castelsardo, Sassari, (BAR); Secca di Castelsardo, -40, 3 sh (BAR); Aranci Gulf, 1 (NOF); Arzachena, Sassari, 1 sh (DON); Porto S. Paolo, Sassari, 1 sh (DON); Punta Marana, Sassari, 1 sh (TRI); Stintino, Sassari, 1 sh (RUF); S'Archittu, Oristano, 24 sh (SOS); Cagliari, 2 sh (PIS); Poetto, Cagliari, 2 sh (PIS); Sant'Antioco, Carbonia-Iglesias, $10 \mathrm{sh}$ (PIS); Calasetta, Carbonia-Iglesias, 1 sh (PIS).

Sicily. S. Raineri, Messina, 1 sh (MCZR-M16877); Pace, Messina, 1 sh (VIL); Ficarazzi, Palermo, 7 sh (PUS); Isola delle Femmine, Palermo, 4 sh (PUS legit Bagnera), 11 sh (SER); Ustica Isl., 3 sh (VIL); Palermo, 3 sh (HUJ coll. Coen, Hebrew Univ. sub nomine Philbertia purpurea bicolor, lot 1914B), 2 sh (HUJ lot 8071 with Monterosato's label "Philbertia densa", 2 sh MCZR-M-16806 sub nomine Philbertia atropurpurea var. minor), $7 \mathrm{sh}$ (PUS); Trapani, 1 sh (SER), sh (MCZR-M-16807); S. Giuliano, Trapani, 5 sh (PAL); Acitrezza, Catania, 1 sh (SMNH lot 73198E); Cannizzaro, Catania, 1 sh (PAG); S. Giovanni Li Cuti, Catania, 1 sh (VIL); Brucoli, Siracusa, 1 sh (SMNH lot 73206C), 3 sh (PUS); Porto Palo, Siracusa, 1 sh (PAL), 3 sh (GER); Pozzallo, Ragusa, 1 sh (MRSNT lot 18280 sub nomine $R$. reticulata); Pozzallo Porto, Ragusa, 1 sh (CRO); Capo Passero, Ragusa, 1 sh (MAR); Lampedusa Isl., 1 sh (PAG).

Croatia. Krk Island, 14 sh (BAR).

Tunisie. Djerba Island, 1 sh (PUS); Gulf of Gabes, 5 sh (SMNH, lot $73177 \mathrm{G})$.

Greece. Kalymnos Island, 1 sh (RAV); Simi Island, 1 sh (SMNH lot 25329a); Malia, Crete, 1 sh (CRO); Pefko, Skiros Isl., -6 m, 4 sh (CRO); Plataria, Igoumenitsa, $-6 \mathrm{~m}, 3$ sh (CRO).

Turkey. Bozcaada Island, 1 sh (PUS).

Egypt. Alexandria, 1 sh (PUS).
DESCRIPTION. In square brackets the data of the holotype. Shell fusiform, of medium size for the genus, height 8-16.4 mm, mean: 11.18 DS: 2.1 [11.7]; width 3-6 mm, mean: 4.24 DS: 0.69 [4.6]; H/W 2.32-2.86, mean: 2.63 DS: 0.16 [2.54].

Protoconch multispiral of 3 convex whorls, heigth $458 \mu \mathrm{m}$, width $415 \mu \mathrm{m}$, protoconch I of 1 whorls, width $235 \mu \mathrm{m}$, covered by thin cancellations, protoconch II with a diagonally cancellated sculpture starting after a zone under the suture with fine axial threads. The last whorl show a short keel before the onset of the teleoconch. Protoconchteleoconch boundary slightly flexuose, opisthocline.

Teleoconch of 7-9 [7] convex whorls, slender and stout, suture incised, sculpture robust. Densely disseminated microgranules in the surface. Axial sculpture of 16-29 mean 21 DS 3.5 [21] orthocline, equidistant ribs, and interspaces slightly narrower than the ribs. Spiral sculpture of 6-9 mean 7 DS 0.91 [7] cordlets above the aperture. Cancellation rectangular, with strong and sligthly acute tubercles at the intersection of axials and spirals. Subsutural ramp narrow, with small tubercles in correspondence with the axial ribs tip and one or two small spiral cordlets.

Columella simple, slightly sinuous anteriorly, gently angled posteriorly. Siphonal channel short. Outer lip with 10-14 mean 11 DS 1.38 [11] strong inner lyrate denticles, the most posterior is shorter. Siphonal fasciole with 6-10 strong nodulose cords [8] mean 8 DS 0.89 .

Colour uniformly orange brown in the background (from ligth to dark), with large ashy blotches, as wide as 1-3 axial ribs. Suprasutural cordlet (rarely two) at least on the last whorl. Comma-shaped ashy spots on the subsutural ramp. Enterely white specimens are known. Soft parts unknown.

Distribution AND Biology. The entire Mediterranean, Canary Islands (Tenerife). In the Mediterranean Sea, species of Raphitoma are usually active at night time, and live mostly on soft bottoms, 0 $100 \mathrm{~m}$ depth, ranging from coastal bioclastic coarse sands to muddy bioclastic coarse sands, but also in sandy pockets amidst rocks or phanerogams meadows, although it is not infrequent to find specimens hiding under stones and in crevices, especially at daytime. One species ( $R$. pseudohystrix) has been found in bottoms down to $700 \mathrm{~m}$ depth. 


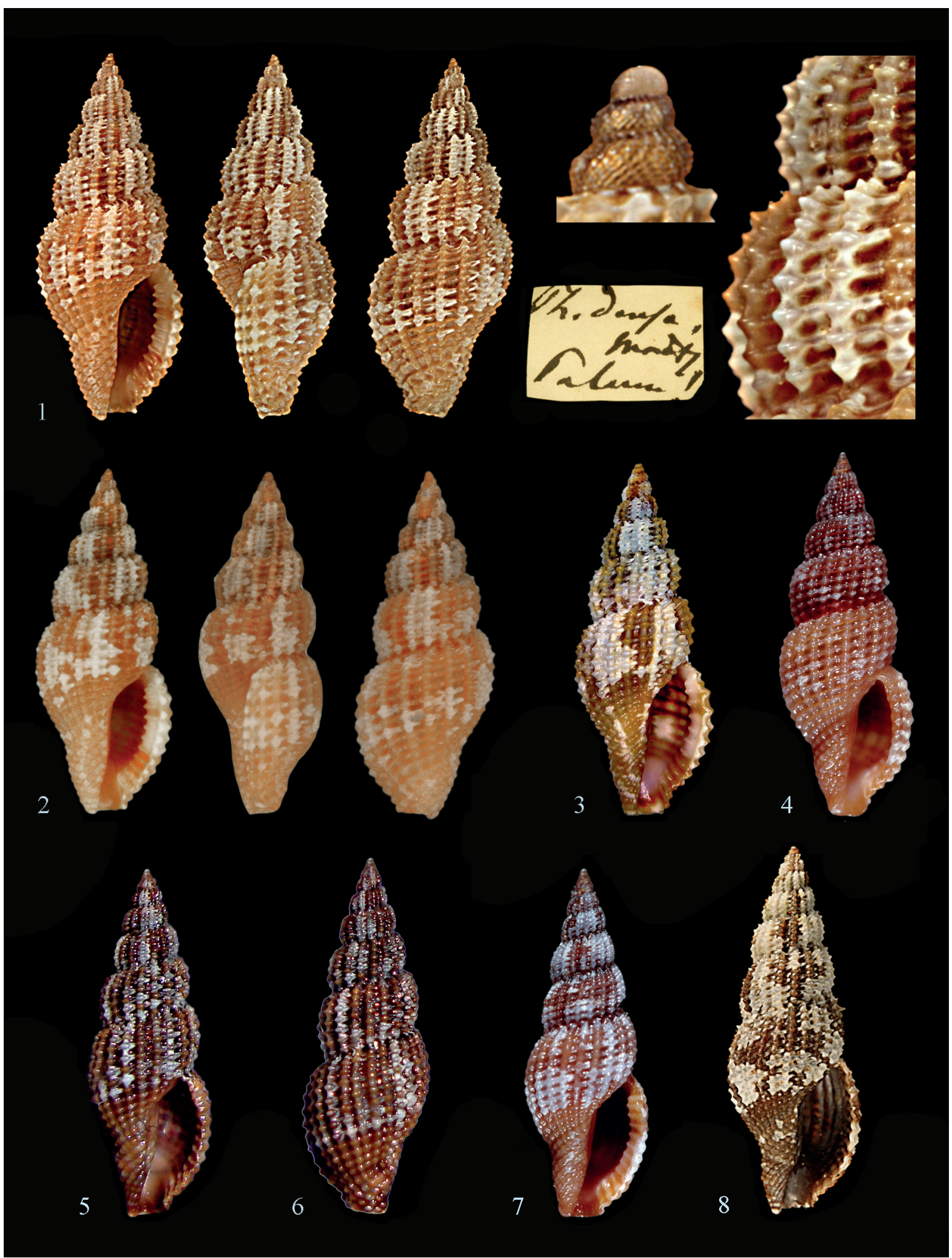

Figures 1-8. Shells of Raphitoma densa. Fig. 1: Lectotype, Palermo, Italy (MCZR-M 16807), h: 11.7 mm; Fig. 2: Trapani (Italy), h: $11 \mathrm{~mm}$; Fig. 3: Torre Astura, Latina (Italy), h: 12 mm; Fig. 4: Toulon (France), h: 13.2 mm; Fig. 5: Ladispoli (Roma), h: 10 mm; Fig. 6: Ladispoli, Roma (Italy), h: 11 mm; Fig. 7: St. Raphael (France), h: 9.9 mm; Fig. 8: Castiglioncello (Livorno), h: $11.8 \mathrm{~mm}$. 


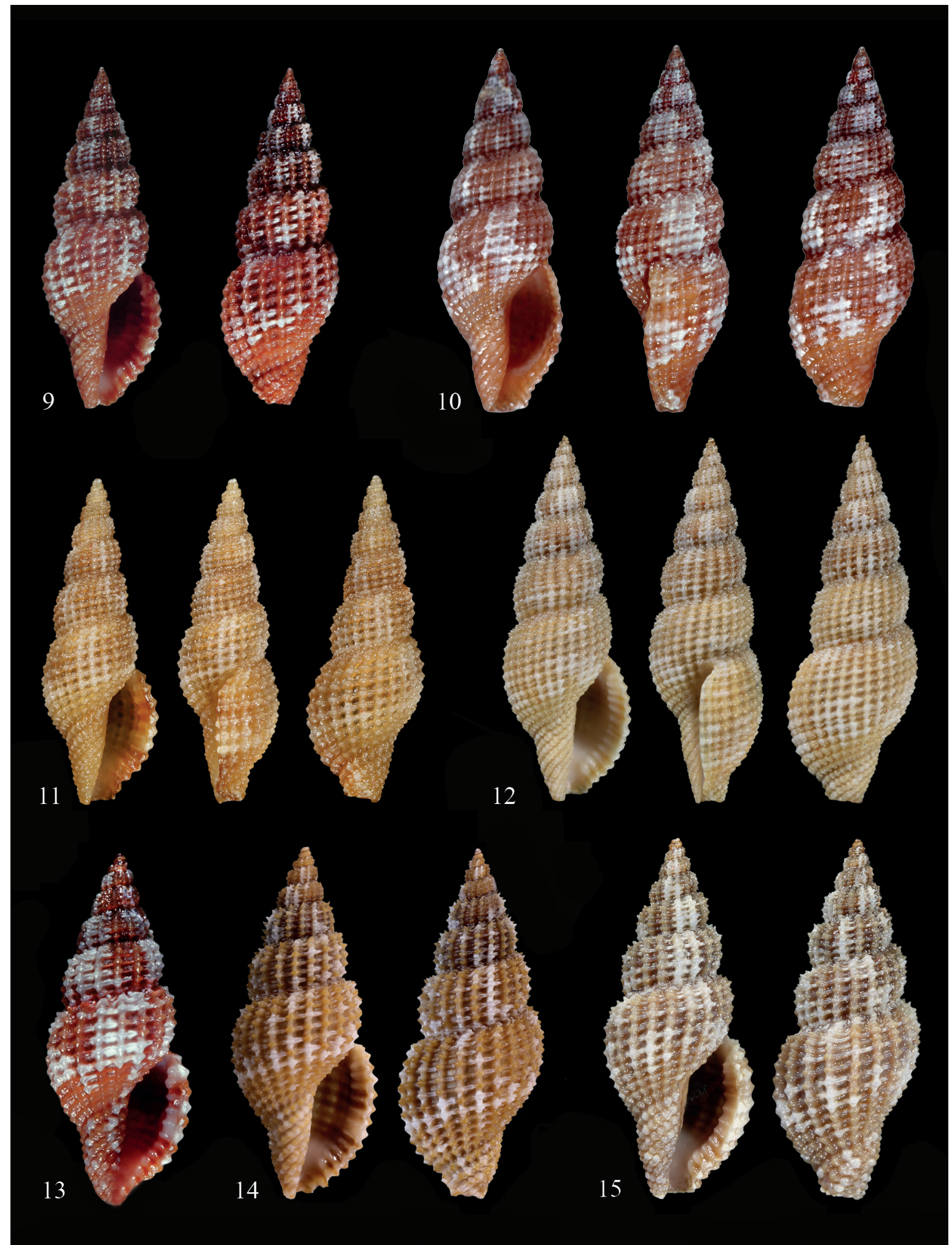

Figures 9-15. Shells of Raphitoma densa. Fig. 9: Posillipo (Italy), h: 12.8 mm; Fig. 10: St. Raphael (France), h: 13.1; Fig. 11: Palermo (Italy), h: 10.4 mm; Fig. 12: Napoli (Italy), h: 16.2; Fig. 13: Golfo di Baratti (Italy), h: 8.1 mm; Fig. 14: St. Raphael (France), h: 8.5 mm; Fig. 15: Brucoli, Siracusa (Italy), h: 10.5 mm. 


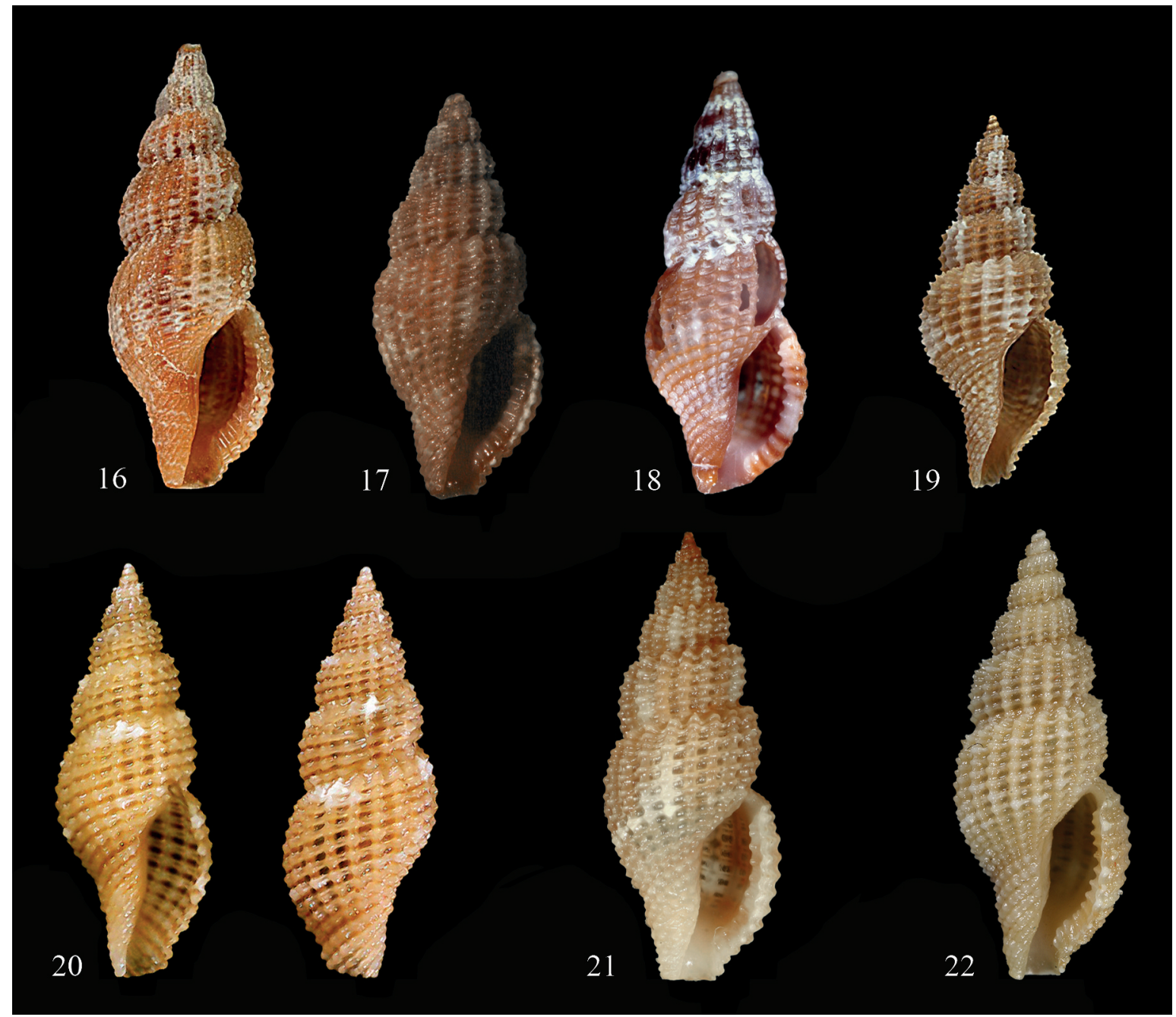

Figure 16. Clathurella decorata. Lectotype, St. Raphael (France), h: 12.7 mm; Figure 17. Clathurella bucquoyi Locard, 1891. Paralectotype, Ajaccio, Corse (France), h: 8 mm; Figure 18. Raphitoma (Philbertia) bourguignati tarentina. Holotype, Taranto (Italy), h: 9.7 mm; Figure 19. R. (Ph.) flavida. Lectotype, Ibiza Isl. (Spain), h: 7.4 mm; Figure 20. R. lineolata, Saronic Gulf (Greece), h: $7 \mathrm{~mm}$; Figure 21. R. corbis, Termini Imerese, Palermo (Italy), h: $10.3 \mathrm{~mm}$; Figure 22. $R$. corbis, Isola delle Femmine, h: $10.5 \mathrm{~mm}$

REMARKS. Scacchi (1836: 13) described Pleurotoma versicolor. The type material seem to be lost (Nicola Maio, pers. comm. and Cretella et al., 2004: 123), but from the original description seems that more than one species are involved, i.e., $R$. philberti, R. bicolor and R. densa. Moreover the additional $P$. versicolor var. cinereo-maculata Scacchi, 1836 is a nomen nudum.

Locard (1891: 67) introduced Clathurella decorata. In the Locard collection at MNHN Paris we found 3 lots of this species. One contain 2 specimens from Marseille that are related to $R$. atropur- purea (Locard \& Caziot, 1899), one contain 2 specimes from Toulon also related to $R$. atropurpurea and a third one containing 4 specimens from St. Raphael related to $R$. densa (Monterosato, 1884). To maintain the nomenclatural stability we designed from this last lot as lectotype a specimen of $\mathrm{mm} 12.7$ x 4.8. So C. decorata Locard, 1891 become a synonym of Philbertia densa Monterosato, 1884 that take precedence (Fig. 16).

Locard (1886) introduced C. bucquoyi (a name available by indication (I.C.Z.N., 1985: Art. 12.2.1). To stabilize the use of this name we designate (Gi- 
annuzzi Savelli et al., 2018: 19) the specimen from Saint Lunaire figured by B.D.D. (1883: figs. 13, 14; as "Clathurella purpurea var. philberti Michaud"), a typical R. oblonga.

Only subsequently did Locard (1891) provide an extensive description of C. bucquoyi, reporting it as common in the Mediterranean, but unfortunately mixing it with other species of the $R$. bicolor group (not identifiable as lacking protoconch), including $R$. densa.

So we assume that there are two C. bucquoyi, one from 1886 and one from 1891.

Among the type material from $C$. bucquoyi, there are two paralectotype from Ajaccio and three from St. Raphael, all related to $R$. densa (Fig. 17).

Nordsieck (1977: 55 pl. 17 n. 136) introduced Raphitoma (Philbertia) bourguignati tarentina. The type material in SMF consists in the holotype from Taranto, $\mathrm{mm} 9.7 \times 3.6$ ed a paratype $(\mathrm{mm} 10.5 \times$ 3.9) labelled "Cataldo, Adria" [probably San Cataldo, Lecce, Adriatico]. The holotype is clearly a specimen of $R$. densa and the paratype is related to $R$. atropurpurea (Fig. 18).

Again, Nordsieck (1977: 54, pl. 17 n. 132) introduced Raphitoma (Ph.) flavida Monterosato, 1884. Unfortunately, Monterosato never described a species with this name. Monterosato (1875: 55) introduced a Pleurotoma (Defrancia) purpurea var. flavida, but this is a nomen nudum. Again, Monterosato (1878: 106) introduced Pleurotoma corbis var. flavida, but this too is a nomen nudum.

So the name Raphitoma flavida should be credited to Nordsieck, 1977 that also give a description.

The type material consist in 3 lots. One from Ibiza (SMF lot 337099/28 with original manuscript label Philb. purp. flavida Mts/Ibiza) containing 12 shells and 1 fragment. Ten shells and the fragment are referable to $R$. densa, of the other two (both with traces of multispiral protoconchs), one is not identifiable and the other seem to be a juvenile of $R$. corbis. One (SMF lot 337100/1) with original ms label "Philbertia flavida Mts/ S' Pol de Mar" contain 1 shell referable again to $R$. densa. A third one SMF lot 337101/1 with original $\mathrm{ms}$ label "Philb. flavida Mts/Sfax" contain 1 shell still referable to $R$. densa.

Then we designate as lectotype a specimen from lot 337099/28 coming from Ibiza, mm 7.4 x 3.0 with incomplete peristome (Fig. 19).

Thus, R. flavida Nordsieck, 1977 becomes a junior synonym of $R$. densa.
Raphitoma densa differs from $R$. lineolata (B.D.D., 1883) (Fig. 20) for to the lack of the characteristic brown spirals on the background and for the ashy blotches vs. whitish on the background.

From R. corbis (Potiez et Michaud, 1838) (Figs. $21,22)$ it differs for its characteristic ashy blotches and for less evident sculpture.

Raphitoma griseomaculata Pusateri et Giannuzzi-Savelli n. sp. - Figs. 23-26, 32

Raphitoma cfr. alternans Manousis et al., 2018: 5; fig. $3 \mathrm{c}$

TYPe MATERial. Holotype mm 13.9 x 5.5 and paratype A mm $10.6 \times 4.4(\mathrm{MNHN})$, paratype B mm 11.6 x 4.6 (PUS), paratype C mm 10.1 x 4.2 (FIO) all from type locality (legit A. Fiorita \& M. Perini).

TyPe Locality. 1 mile off Torre Squillace, Porto Cesareo (Lecce) -20/30 m 40 $13^{\circ} \mathrm{N}-17^{\circ} 50^{\prime} \mathrm{E}$

EXAMINED MATERIAL. Only the type material.

Description of THE holotype. Shell slender fusiform, of medium size for the genus, height: 13.9 $\mathrm{mm}$, width: $4.7 \mathrm{~mm}$. H/W: $2.53 \mathrm{~mm}$.

Protoconch paucispiral (Fig. 32). Only protoconch I of 0.9 convex whorls, height: $230 \mu \mathrm{m}$, width: $225 \mu \mathrm{m}$; sculpture with horizontally elongated rectangles. In the last part there are fine curved axial threads in the subsutural zone. Protoconch-teleoconch boundary indistinct but flexuose.

Teleoconch of 6 convex whorls, solid, suture evident, medium-strength sculpture. No microgranules on the surface. Axial sculpture of 20 slightly opisthocline, equidistant, robust ribs, and interspaces 1.1 as wide as the ribs. Spiral sculpture of 8 cordlets above the aperture, narrower than the axials. Cancellation rectangular, with strong and slightly elongated (acute in the first whorls) tubercles at the intersections.

Subsutural ramp very short. Columella simple, slightly sinuous anteriorly, gently angled posteriorly. Outer lip with 11 elongated inner denticles, the most anterior delimiting the short and wide siphonal canal is smaller than other, the most posterior delimiting the shallow anal sinus is smaller than the others. Siphonal fasciole with 9 nodulose cords. 


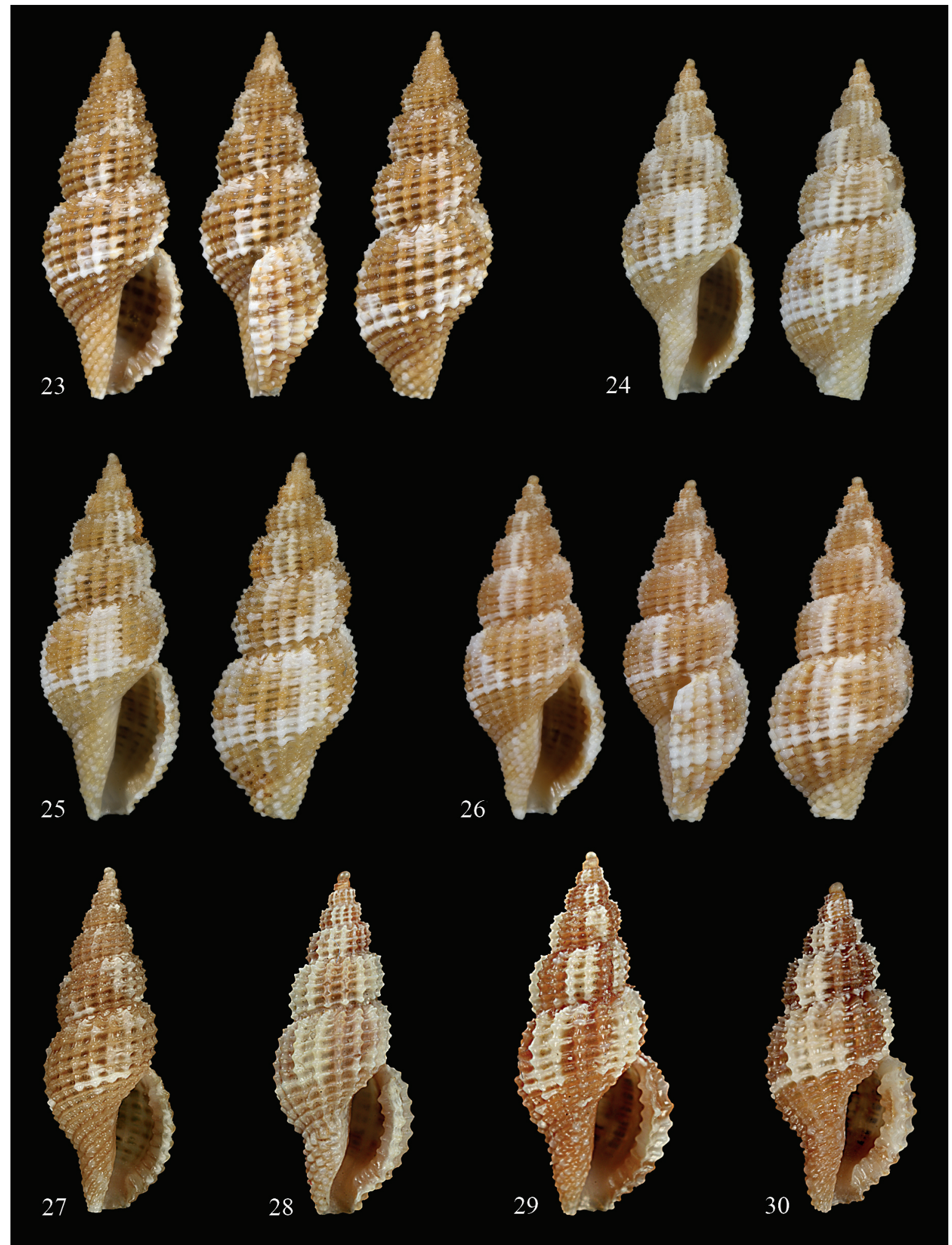

Figures 23-26. Shells of Raphitoma griseomaculata n. sp. Torre Squillace, Porto Cesareo, Lecce (Italy). Holotype, h: 13.9 mm; paratype A, h: $10.6 \mathrm{~mm}$; paratype B: h: $11.6 \mathrm{~mm}$; paratype C: h: $10.1 \mathrm{~mm}$. Figure 27. R. smriglioi, holotype, Ognina, Siracusa (Italy), h: $9.4 \mathrm{~mm}$. Figure 28. R. philberti, Palermo (Italy), h: $8.5 \mathrm{~mm}$. Figure 29. R. papillosa, Djerba Isl. (Tunisia), h: $9.7 \mathrm{~mm}$. Figure 30. Raphitoma farolita, Cannizzaro, Catania (Italy), h: $7.5 \mathrm{~mm}$. 

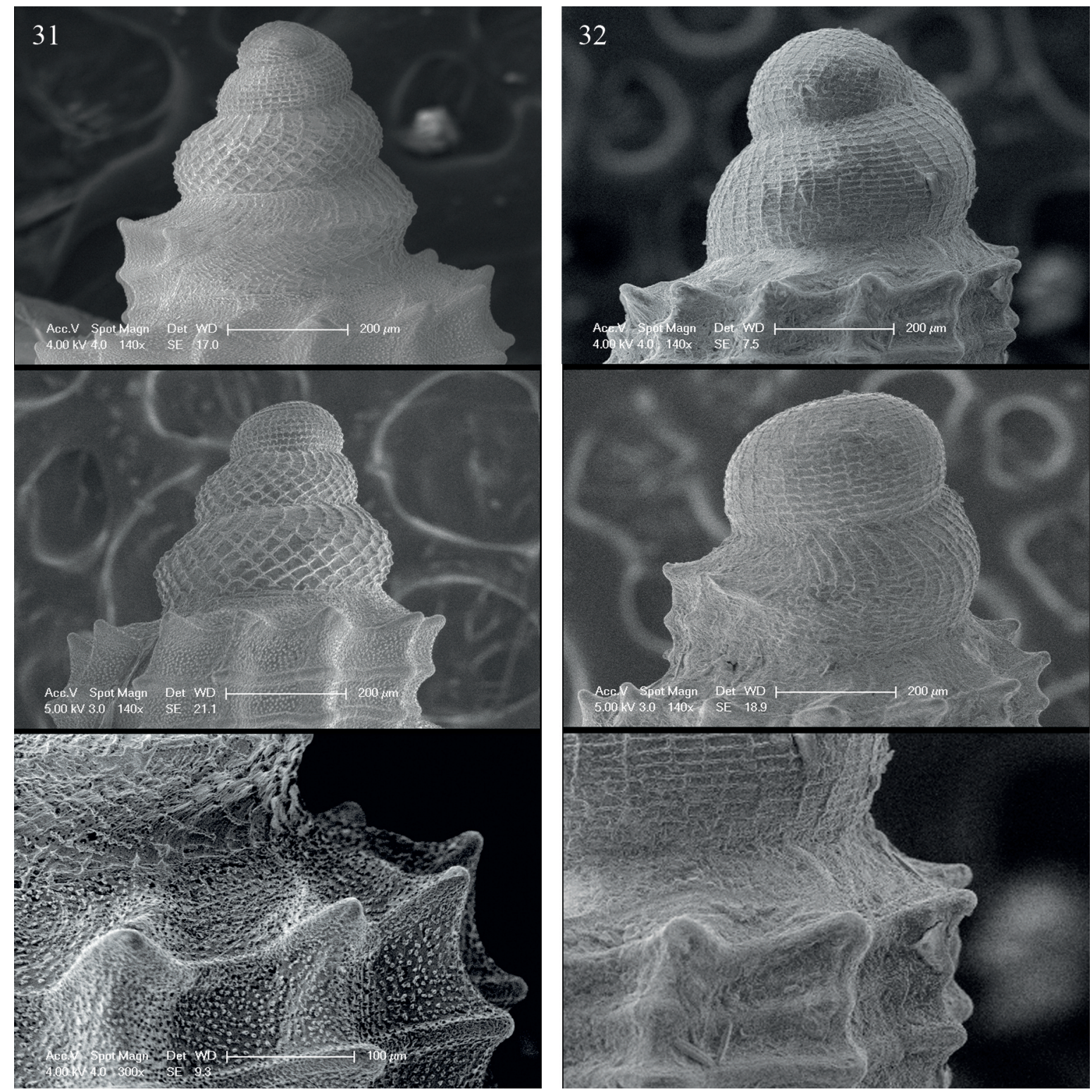

Figure 31. Raphitoma densa, protoconch. Figure 32. Raphitoma griseomaculata n. sp., protoconch.

Colour uniformly straw yellow (the background, with ashy blotches). Suprasutural cordlet same colour as the blotches, at least on the last whorl.

Soft parts unknown.

VARIABILITY. The paratypes have: height: 10-14 $\mathrm{mm}$, width: $4.2-5.5 \mathrm{~mm}, \mathrm{H} / \mathrm{W}: 2.38-2.53$. Teleoconch of 7-8 convex whorls. Axial sculpture of 2024 ribs, and interspaces from 1 to 1.5 as wide as the ribs. Spiral sculpture of $8-10$ cordlets above the aperture. Sometime one supplementar secondary cordlet can occur. Outer lip with 11-14 elongated inner denticles. Siphonal fasciole with 9-10 nodulose cords. Colour uniformly straw yellow to yellow orange.

ETYMoLOGy. A compound noun derived from the latin words "griseus" = gray, and "maculatus" = spotted, speckled.

Distribution. This species is only known due to the type locality: Torre Squillace, Porto Cesareo (Lecce, Italy). 
REMARKS. $R$. griseomaculata $\mathrm{n}$. sp. differs from R. smriglioi Pusateri et Giannuzzi-Savelli, 2013 having a different protoconchs (more regular profile vs. semi-strangled upper outline and a slight keel in the low part) for to the lack of the characteristic brown spirals of the background and the color (paler in R. griseomaculata n. sp. and more saturated in the $R$. smriglioi).

The new species differs from the light $R$. philberti (Michaud, 1829) having his blotches neat and not vanishing, the outline less slender and the lacking of one subsutural ramp.

Raphitoma papillosa (Pallary, 1904) have a more strong sculpture and the blotches are not ashy grey.

Raphitoma farolita (Nordsieck, 1977) is much more robust and less slender (HD: 2.15-2.24 vs. 2.38-2.53) than $R$. griseomaculata and blotches are pure white.

\section{ACKNOWLEDGMENTS}

We thank all the friends mentioned above with their acronyms, who made the material of their collections available to us for study. The following colleagues are deeply thanked for their help with Museum samples under their care: Bruno Cignini and Massimo Appolloni (MCZR), Philippe Bouchet, Virginie Héros, Pierre Lozouet, and Philippe Maestrati (MNHN), Ronald Janssen (SMF), Anders Warén (SMNH). In particular, we would like to thank Carlo Smriglio and Andrea Di Giulio (Roma, Italy) for their patience and constant collaboration.

\section{REFERENCES}

Arduino G., Locatelli B., Orlando F. \& Repetto G., 1995. Catalogo illustrato delle conchiglie marine del Mediterraneo. Clavesana, Langa Grafica, 197 pp.

Bellardi L., 1847. Monografia delle Pleurotome fossili del Piemonte. Memorie della Reale Accademia delle Scienze di Torino, serie 2, 9: 531-650, 4 pls. [R. Janssen, 1993, said that the journal issue was published in 1848 but that a separate was distributed in 1847; the title and pagination for the separate is: Monografia delle Pleurotome Fossili del Piemonte. Torino, 119 pp.].
Bucquoy E., Dautzenberg P. \& Dollfuss G., 1883. Les mollusques marins de Roussillon. Tome premier: Gastropodes avec atlas de 66 planches. Paris: J.-B. Baillière \& Fils. 570 pp., 66 pls. [Turrids are in fascicule 1 (3): 85-135, pls. 11-15].

Bouchet P., 1989. A review of poecilogony in gastropods. Journal of Molluscan Studies, 55: 67-78.

Bouchet P., 1990. Turrid genera and mode of development: the use and abuse of protoconch morphology. Malacologia, 32: 69-77.

Bouchet P., Kantor Y.I., Sysoev A. \& Puillandre N., 2011. A new operational classification of the Conoidea. Journal of Molluscan Studies, 77: 273-308.

Cachia C., Mifsud C. \& Sammut P.M., 1993. An Annotated Check-List of the Marine Mollusca of the Maltese Islands. Erste Vorarlberger Malakologische Gesellschaft, Rankweil, Austria, 81 pp.

Cachia C., Mifsud C. \& Sammut P.M., 2001. The Marine Mollusca of the Maltese Islands Part Three Sub-Class Prosobranchia to Sub-Class Pulmonata, Order Basommatophora. Backhuys Publishers, Leiden, 266 pp.

Carus J.V., 1893. Prodromus Faunae Mediterraneae sive Descriptio Animalium Maris Mediterranei Incolarum quam Comparata Silva rerum Quatenus Innotuit Adiectis Locis et Nominibus Vulgaribus. Vol. II. Brachiostomata. Mollusca. Tunicata. Vertebrata. E. Schweizerbart'sche, Stuttgart, ix +854 pp.

Cossignani T. \& Ardovini R., 2011. Malacologia Mediterranea. Ancona, L'Informatore Piceno, pp. 536

Cretella M., Crovato C., Crovato P., Fasulo G. \& Toscano F., 2005. The malacological works of Arcangelo Scacchi (1810-1893). Part II: A critical review of Scacchian taxa. Bollettino Malacologico, 40: 114-131.

Crosse H., 1885. Nomenclature generica e specifica di alcune Conchiglie Mediterranee, pel marchese di Monterosato [book review]. Journal de Conchyliologie, 33: 139-142.

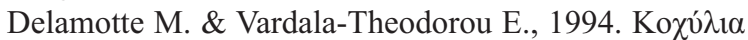

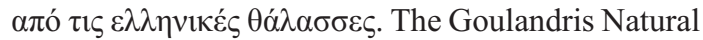
History Museum, Kifissia, 317 pp.

Giannuzzi-Savelli R., Pusateri F. \& Bartolini S., 2018. A revision of the Mediterranean Raphitomidae (Gastropoda, Conoidea) 5: Loss of planktrophy and pairs of species with the description of four new species. Bollettino Malacologico, Suppl. 10, vol. 54: $1-77$.

Hidalgo J.G., 1917. Fauna malacológica de España, Portugal y las Baleares. Moluscos testáceos marinos. Trabajos del Museo Nacional de Ciencias Naturales, Serie Zoológica, 30: 1-752.

I.C.Z.N. (International Commission on Zoological Nomenclature), 1985. Internatiional Code of Zoological Nomenclature. Third Edition. The International Trust for Zoological Nomenclature, London, $\mathrm{xx}+$ $338 \mathrm{pp}$. 
Jablonski D. \& Lutz R.A., 1980. Larval shell morphology: ecological and paleontological applications. In: Rhoads D.C. \& Lutz R.A. (Eds.), Skeletal growth of aquatic organisms. Plenum, New York, pp. 323377.

Kantor Y.U.I. \& Taylor J.D., 2002. Foregut anatomy and relationships of raphitomine gastropods (Gastropoda: Conoidea: Raphitominae). In: Oliverio M. \& Chemello R. (Eds.), Systematics, Phylogeny and Biology of the Neogastropoda. Bollettino Malacologico, Supplement 5: 161-174.

Locard A., 1886. Prodrome de malacologie Française. Catalogue général des Mollusques vivants de FranceMollusques marins. Lyon, Henri Georg and Paris, J.B. Baillière et Fils. $x+778$ pp.

Locard A., 1891. Les coquilles marines des côtes de France. Annales de la Société Linnéenne de Lyon, 37: $1-385,348$ figs. [Also published as a separate in 1892]

Manousis T., 2012. The sea shells of Greece. Thessaloniki, Kyriakidis Brothers S.A, 381 pp.

Manousis T., Kontadakis C., Mbazios G. \& Polyzoulis G., 2018. The family Raphitomidae (Mollusca: Gastropoda: Conoidea) in the Greek Seas with the description of two new species. Journal of Biological Research-Thessaloniki, 25: 1-38.

Monterosato M. di, 1872. Notizie Intorno alle Conchiglie Mediterranee. Michele Amenta, Palermo, $61 \mathrm{pp}$.

Monterosato M. di, 1875. Nuova rivista delle conchiglie mediterranee. Atti dell'Accademia di Scienze, Lettere ed Arti di Palermo, nuova serie, 5: 1-50.

Monterosato M. di, 1878. Enumerazione e sinonimia delle conchiglie mediterranee. Giornale Scienze Naturali ed Economiche, Palermo 13: 61-115.

Monterosato M. di, 1884. Nomenclatura generica e specifica di alcune conchiglie mediterranee. Palermo, Stab. Tip. Virzì, 152 pp.

Monterosato M. di, 1917. Molluschi viventi e quaternari raccolti lungo le coste della Tripolitania dall'ing. Camillo Crema. Bollettino Società Zoologica Italiana, serie III, 4: 1-28, with 2 pls.

Nordsieck F., 1968. Die Europäischen Meeres-Gehäuseschnecken (Prosobranchia) vom Eismeer bis Kapverden und Mittelmeer. Gustav Fischer, Stuttgart, viii +273 pp., 33 pls.

Nordsieck F., 1977. The Turridae of the European Seas. Roma, Ed. La Piramide, pp. 131, 26 pls.

Oliverio M., 1996a. Life-histories, speciation and biodiversity in Mediterranean prosobranchs gastropods. Vie et Mileu, 46: 163-169.

Oliverio M., 1996b. Chapter 22. Contrasting developmental strategies and speciation in N.E. prosobranchs: a preliminary analysis. In: Taylor J.D.
(Ed.), Origin and evolutionary radiation of the Mollusca, Oxford University Press, pp. 261-266.

Oliverio M., 1997. Global biodiversity and life-history evolution in prosobranchs gastropods. Iberus, 16: 73-79.

Pallary P., 1900. Coquilles marines du littoral du Départment d'Oran. Journal de Conchyliologie, 48: 211422, pls. 6-8.

Pallary P., 1912. Catalogue des mollusques du littoral méditerranéen de l'Egypte. Mémoires de l'Institut d'Egypte, 7: 69-207, pl. 15-18.

Parenzan P., 1970. Carta d'identità delle conchiglie del Mediterraneo, volume primo Gasteropodi. Taranto, Ed. Bios Taras, 283 pp.

Piani P., 1980. Catalogo dei molluschi conchiferi viventi nel Mediterraneo. Bollettino Malacologico, 16: 113224.

Poppe G.T. \& Goto Y., 1991. European Seashells. Volume 1 (Polyplacophora, Caudofoveata, Solenogastra, Gastropoda). Verlag Christa Hemmen, Wiesbaden, Germany, 352 pp.

Puillandre N., Fedosov A.E. \& Kantor Y.I., 2017. Systematics and Evolution of the Conoidea. In: Evolution of Venomous Animals and Their Toxins, 367-398.

Repetto G., Bianco I. \& Ciccimarra G., 2011. Conchiglie Mediterranee Dizionario dei nomi scientifici (Il significato di 2100 nomi). Ancona, Informatore Piceno, $408 \mathrm{pp}$.

Repetto G., Orlando F. \& Arduino G., 2005. Conchiglie del Mediterraneo. Alba, Ed. Amici del Museo "Federico Eusebio", 392 pp.

Sabelli B., Giannuzzi-Savelli R. \& Bedulli D., 19901992. Catalogo Annotato dei Molluschi Marini del Mediterraneo. Vols. 1-3. Edizioni Libreria Naturalistica Bolognese, Bologna, xiv +781 pp.

Scacchi A., 1836. Catalogus conchyliorum regni Neapolitani quae usque adhuc reperit. Napoli: Filiatre Sebetii. 18 pp., 1 pl. [Also a reprint attributed to Albertus Detken and published by Francisci Xavierii Tornese in 1837 which contains the same information but is condensed into 13 pp.; citations in the text are based on the original edition.]

Scaperrotta M., Bartolini S. \& Bogi C., 2018. Accrescimenti - Stadi di accrescimento dei molluschi marini del Mediterraneo vol. 9. Ancona, Informatore Piceno, $192 \mathrm{pp}$.

Trono D., 2006. Nuovi dati sulla malacofauna del Salento (Puglia meridionale). Bollettino Malacologico, 42: 58-84.

Trono D. \& Macrì G., 2013. Malacofauna del Salento (Trono, 2006): Corrigenda e Addenda. Bollettino Malacologico, 49: 26-48. 